\title{
Intelligent Designing and Increasing the Variability of Healthy Residential Buildings by Customizing Recycled Polyvinyl Butyral
}

\author{
Annamária Behúnová ${ }^{1, *}$, Lucia Knapčíková ${ }^{2} \mathbb{D}$, Marcel Behún ${ }^{1}$, Tomáš Mandičák ${ }^{3} \mathbb{C}$ and Peter Mésároš ${ }^{3}$ \\ 1 Faculty of Mining, Ecology, Process Control and Geotechnologies, Institute of Earth Resources, The Technical \\ University of Košice, 04384 Košice, Slovakia; marcel.behun@tuke.sk \\ 2 Department of Industrial Engineering and Informatics, Faculty of Manufacturing Technologies, \\ The Technical University of Košice, 08001 Prešov, Slovakia; lucia.knapcikova@tuke.sk \\ 3 Department of Technology, Economy and Management in Construction, Faculty of Civil Engineering, \\ The Technical University of Košice, 04200 Košice, Slovakia; tomas.mandicak@tuke.sk (T.M.); \\ peter.mesaros@tuke.sk (P.M.) \\ * Correspondence: annamaria.behunova@tuke.sk
}

Citation: Behúnová, A.; Knapčíková, L.; Behún, M.; Mandičák, T.; Mésároš,

P. Intelligent Designing and

Increasing the Variability of Healthy

Residential Buildings by Customizing

Recycled Polyvinyl Butyral.

Sustainability 2021, 13, 9073.

https://doi.org/10.3390/

su13169073

Academic Editor: Helena Corvacho

Received: 1 July 2021

Accepted: 10 August 2021

Published: 13 August 2021

Publisher's Note: MDPI stays neutral with regard to jurisdictional claims in published maps and institutional affiliations.

Copyright: (c) 2021 by the authors. Licensee MDPI, Basel, Switzerland. This article is an open access article distributed under the terms and conditions of the Creative Commons Attribution (CC BY) license (https:// creativecommons.org/licenses/by/ $4.0 /)$.

\begin{abstract}
Healthy residential buildings represent the future of construction concerned with the environment, which is increasingly emphasized. This is directly related to the research and development of environmentally friendly building materials, which on the one hand meet the specific requirements of the builder, and on the other hand do not harm the environment. The research is based on the possibility of achieving increased variability in healthy residential buildings via the customization of recycled polyvinyl butyral using smart technologies for sustainable design. This study has two sub-goals; the first and foremost is the development and adaptation of recycled polyvinyl butyral to increase the elevation of the healthy residential buildings. The second objective is to design a methodology, and create databases and intelligent designs, via knowledge and building information modeling (BIM) technologies. In future research, data on environmental materials (such as the abovementioned recycled polyvinyl butyral) should be implemented in the knowledge databases that will be methodically described in our second sub-target.
\end{abstract}

Keywords: variability; customization; FMD; sustainable material; BIM

\section{Introduction}

The design of healthy residential buildings is one of the EU's environmental objectives [1]. In the current period where there are extensive discussions taking place on emissions and many searches for ways to eliminate adverse environmental pollution factors, building healthy residential areas is very important. Many studies deal with this issue [2]. Several experts share the same approaches to achieving this goal [3]. The choice of suitable environmentally safe materials is one way to achieve this goal [4]. In addition, examining the effects of individual building materials on human health and their environmental impacts should be a priority [5]. However, knowledge of the properties of the current materials is not enough. It is essential to seek and develop other environmentally suitable building materials that will have the desired properties and positive impacts on human health [6]. Adjusting the individual components with which we can produce Teito building materials should be a further step, supported by a specified objective in healthy housing. Therefore, the development, testing, and implementation of components and materials should be supported to the greatest extent in construction. Sustainable construction is based on multiple pillars. Sustainable and suitable materials are one of them. Therefore, the adjustment and selection of materials should occur based on predetermined parameters that reflect the requirements and characteristics of healthy housing $[2,7,8]$. 
Implementing so-called healthy and environmentally safe materials is often the most challenging step, which presents multiple barriers. Therefore, it is crucial that the planning and design of buildings be carried out to support the selection of such materials, and to allow their straightforward implementation. Intelligent and knowledge technologies represent an effective tool, as they achieve these ends. BIM (building information modeling) technologies are not used to their maximum potential. However, the development and implementation of BIM and knowledge technologies holds excellent potential for the intelligent design of buildings, and specifically when choosing materials with specific properties $[9,10]$. This would allow the selection of specific properties of building materials and their adaption to the needs of the building. Building knowledge databases and technologies and implementing information can help in the sustainable design of buildings in terms of the materials required. Thus, the entire building's materials may already be selected based on concrete parameters. This represents a second dimension to achieving an increase in the variability of healthy residential buildings. Therefore, linking these two approaches (on the one hand, the development and adaptation of materials addressing the requirements of health and safety materials; on the other hand, the development and use of knowledge technologies for intelligent and sustainable design) is likely to be the most effective way to achieve our goal.

Based on the stated goal of the research, in addition to the definition of our procedures and the chosen methodology, it is also necessary to clarify the limitations of the research and the results.

In terms of defining a general approach to intelligent design for all types of construction projects, the constructions for which the verification will be performed must be selected carefully. In terms of the researched material (as described in the following sections), and the construction and implementation of a methodology for the intelligent design of healthy buildings, it is possible that the results will not be the same for all types of construction projects. Specific construction projects include, for example, civil engineering works, or transport constructions, where the assessed material's expected positive effects on health, and the method of intelligent design, may be different, given the different natures of the buildings (residential buildings, office buildings, commercial buildings). Given the issue of residential buildings in particular, it is highly probable that the results of this research will be applicable to different types.

It is important to realize that, in the context of intelligent design and increasing the variability of healthy residential buildings, recycled materials are the way to a better climate. Using recycled polyvinyl butyral (PVB), which has a carbon footprint that is $25 \mathrm{x}$ lower than PVB resin, helps us reduce our environmental footprint while increasing the healthiness and safety of our products.

\section{Materials and Methods}

Polyvinyl butyral (PVB) was invented in 1927 by Canadian chemists Howard W. Matheson and Frederick W. Skirrow. Polyvinyl butyral is a transparent, strong and flexible thermoplastic with high optical purity and good adhesion to a large number of substrates [11]. It is made from polyvinyl alcohol via a reaction with butyraldehyde and formaldehyde; the general molecular formula is $\left(\mathrm{C}_{8} \mathrm{H}_{14} \mathrm{O}_{2}\right)_{n}$, which is shown in Figure 1 . PVB is amorphous; only polymers with a VA (vinyl acetate) content higher than $63.30 \%$ by weight are crystallizable. Its melting point $(\mathrm{Tm})$ is between $171{ }^{\circ} \mathrm{C}$ and $218^{\circ} \mathrm{C}$. PVB is soluble in the following solvents: acetic acid, acetone, methanol, ethanol, 2-propanol, butanol, 2-butoxyethanol, cyclohexanone, benzyl alcohol, 1-methoxy-propanol-2, butyl glycol, n-butyl acetate, ethyl acetate, N,N-dimethylacetamide, N,N-dimethylformamide, $\mathrm{N}, \mathrm{N}$-dimethylsulfoxide. It is also resistant to weak and strong acids and weak and strong bases [11,12]. Since PVB is used as a binder in the processing of ceramics, its removal during the sintering process is indeed crucial to the quality of the final product [1,2]. Under a nitrogen atmosphere, $\mathrm{PVB}$ begins to decompose at $280^{\circ} \mathrm{C}\left(5^{\circ} \mathrm{C} / \mathrm{min}\right.$ increase $)$ and in the air at $200^{\circ} \mathrm{C}$. 


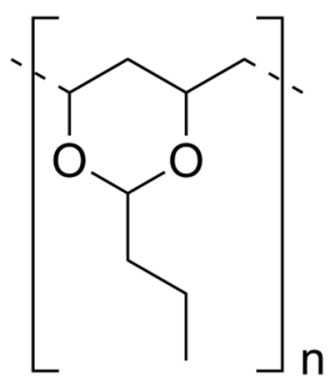

Figure 1. The chemical formula of polyvinyl butyral [12].

The density of PVB ranges from $1.083 \mathrm{~g} / \mathrm{cm}^{3}$, for PVB with a VA content of $11 \%$ by weight $(28.5 \mathrm{~mol} \%)$, to $1.100 \mathrm{~g} / \mathrm{cm}^{3}$, with a VA content of $19 \%$ by weight $(43.1 \mathrm{~mol} \%)$. The hydroxyl groups of PVB are also responsible for their excellent adhesion to many substrates, the most important of which for technological applications is its affinity for glass [12,13]. PVB has been used for more than 50 years to repair and preserve museum objects, such as in glue, impregnators, encapsulants or surface coatings. Studies have shown that the short wavelength region is the most detrimental in terms of PVB photooxidation [13]. Due to its composition, $\mathrm{PVB}$ is very sensitive to the degradation and migration of plasticizers. The thermal oxidation of PVB under mild conditions, such as those that occur during processing $\left(150^{\circ} \mathrm{C}-180^{\circ} \mathrm{C}\right)$, was examined to assess polymer stabilization and long-term aging [12]. Almost all functional groups characteristic of the polymer under investigation are sensitive to the thermal degradation process. UV stabilization of the PVB may be particularly desirable in the context of strong long-term exposure, such as the exposure involved in encapsulating PVB modules [3]. High transparency is also needed to accommodate the effective wavelength, which provides the highest quantum efficiency for specific PVB materials. The effects of UV radiation can be mitigated by the inclusion of a UV absorber such as benzotriazole $(0.2-0.35 \%$ by weight $)$ [13].

\subsection{Recycling of Polyvinyl Butyral}

Interest in recycling PVB waste has increased in recent years. The total amount of PVB films produced, including all industrial applications, was estimated to be around 120.000 tonnes/year, and PVB is currently much less recycled than glass [13,14].

However, its price could be half that of original PVB. The main problem in recycling laminated PVB is the removal of glass from the polymer. Figure 2 presents one possible utilization of recycled polyvinyl butyral.

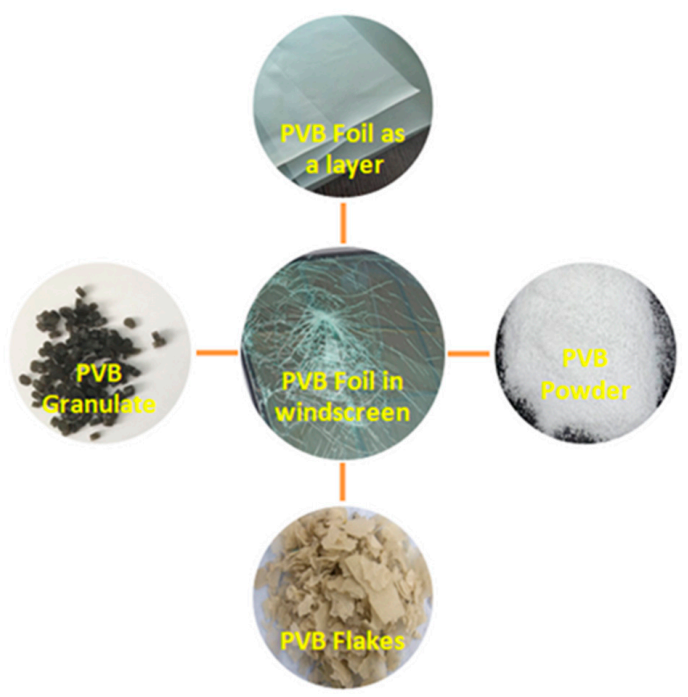

Figure 2. Possibilities for the preparation of recycled PVB for consumers. 
Recycled PVB is divided into three categories. Category 1 contains transparent PVBs (98\% PVB, no impurities), type 2 refers to colorless PVBs (2\% impurities and 96\% PVBs), while category 3 represents colored PVBs (70\% PVBs and 4\% impurities). PVB is obtained from laminated glass by mechanical peeling. More sophisticated and efficient techniques use mechanical cracking in the first stage, followed by chemical separation in an alkaline water solution at $60{ }^{\circ} \mathrm{C}$ and the final automatic cleaning of the glass residues [14].

\subsection{Recycled Polyvinyl Butyral and Possibilities for Its Preparation as an Input Raw Material}

PVB Powder

Thermoplastic polyvinyl butyral resins are supplied as a free-flowing powder (Table 1). The properties of these species, such as their solubility and compatibility with binders and plasticizers, depend on the degree of acetalization and polymerization [11,15]. Increasing the number of butyl groups in the polymer usually improves water resistance and solubility in non-polar solvents. PVB can also be crosslinked [16]. Its crosslinking capacity depends on the number of residual $\mathrm{OH}$ groups in the polymer that can undergo condensation reactions with phenolic, epoxy and melamine resins, as well as isocyanates, to form high-quality solvent-resistant coatings and films [14,15].

Table 1. Basic parameters of PVB powder $[17,18]$.

\begin{tabular}{cc}
\hline & $\begin{array}{c}\text { Material } \\
\text { PVB Powder }\end{array}$ \\
\hline Density & $1.07 \mathrm{~g} \cdot \mathrm{cm}^{-3}$ \\
Molecular weight & $30-45 \mathrm{k}$ \\
Absorbency & $\leq 0.4 \%$ \\
Softening temperature & $60-65{ }^{\circ} \mathrm{C}$ \\
Grain size & $3-5 \mathrm{~mm}$ \\
\hline
\end{tabular}

Due to its good light resistance and excellent transparency, PVB is often used as an interlayer for tear- and break-resistant glass in architectural and automotive areas. PVB resins are also widely used as binders in paints, inks, varnishes, primers, ceramic/metal powders and adhesives.

The big players of PVB manufacturing and supply include the following [15]:

- Eastman (Butvar);

- Kuraray (Mowital);

- $\quad$ Sekisui (S-LEC B);

- $\quad$ ShinEtsu (PVB Copolymer);

- ChangChun Group.

PVB is soluble in most organic/alcohol/ketone/ether/ester organic solvents, and insoluble in hydrocarbon hydroxyl solvents such as petroleum solvents (gasoline). PVB powder is mostly used as a printing ink or a bonding material, or in industry as a corrosionresistant coating with strong anti-corrosion abilities, adhesiveness and resistance for metal bottoms and cold paint [6]. In the ceramic industry, it is used for the production of a bright-colored film. In the plastics industry, it used for the production of molding plastics that replace non-ferrous metals, such as steel and lead, which can be produced in various adhesives $[13,14]$. In the textile industry, PVB powder is used for the manufacturing of textile and yarn treatment agents. In the food industry, it is used for the manufacturing of non-toxic packaging materials. In the paper industry, it is used for the production of paper treatment agents $[15,16]$. In the printing industry, it is applied in gravure printing, screen printing and heat transfer. PVB powder is often used in the manufacturing of laminated glass, adhesives and modified plasticizers, as well as in combination with other polymers, and in antifreeze, reinforcing agents and other waterproofing materials [16].

PVB Flakes

After processing the broken glass, the remaining PVB film is crushed and fed into the various separation processes and cleaning phases. This process is to ensure that foreign, 
interfering substances such as glass, rubber, wood, metals and PVC are removed $[15,16]$. At the end of the recycling process, the colored PVB films are separated. The material is delivered at approx. 20-30 mm. Recycled polyvinyl butyral, used in this research, has the following parameters (Table 2).

Table 2. Material characteristics of recycled polyvinyl butyral $[15,19]$.

\begin{tabular}{cc}
\hline & $\begin{array}{c}\text { Material } \\
\text { PVB Flakes }\end{array}$ \\
Color & \\
Size & colorless \\
Purity & $20-30 \mathrm{~mm}$ \\
Impurities & more than $97 \%$ \\
Residual humidity & less than $3 \%$ \\
Glass transition temperature & ca. $2 \%$ \\
Viscosity (dynamic) & $130-170{ }^{\circ} \mathrm{C}$ \\
MVR (melt volume rate) & $100-175 \mathrm{mPa}^{\circ}(\mathrm{DIN} 53015)$ \\
MFR (melt flow rate) & $6-7 \mathrm{~cm}^{3} \cdot 10 \mathrm{~min}^{-1}$ \\
\hline
\end{tabular}

PVB flakes are used as primers, varnishes, inks, binders (for ceramics, metal powder, abrasives, helmets, pencils, etc.), adhesive additives (rheological aids), hot melt adhesives, foundry tools, cardboard impregnators and reflective warning colors [19].

\subsection{Safety Glass}

PVB is an essential part of light, highly transparent, elastic and durable films. The production of PVB films for laminated safety glass is one of the most important PVB applications [12,13]. The excellent properties of PVB films include toughness, good adhesion to glass, good light resistance and excellent transparency [19]. The foils are responsible for the special safety benefits of laminated safety glass. Laminated safety glass is a combination of two or more annealed or toughened glass panes joined together with one or more PVB films [14]. Therefore, laminated glass is a composite material combining the properties of glass and the properties of a polymer (glass adhesion, elasticity, impact resistance). The synthetic layer has two roles. On the one hand, it dissipates part of the impact energy through viscoelastic deformation. It prevents the projection of fragments, because the glass chips also adhere to the film, thus minimizing the risk of injury. On the other hand, after impact, it retains its residual strength, ensuring the compactness of the glazing $[15,19]$. The interlayers can improve the mechanical performance of the glass and also protect against UV and thermal regulation, while maintaining transparency [17]. High-molecular-weight PVB grades are combined with plasticizers to produce safety glass films. The PVB film is pressed between two glass panels to form tear-resistant laminated safety glass, which is mainly used in the construction and automotive industries [15]. Although other synthetic materials, resins or gels can be used, PVB is most often used for laminated glazing due to its high compatibility with glass, its high transparency, and its remarkable adhesive properties, and finally its viscoelastic properties guarantee high deformability before failure, and maximum attenuation at low frequencies at room temperature [15].

As measured on the laminated glass interlayers, the hydroxyl activity depends on the $\mathrm{pH}$ and the water content of the PVB films [19]. The alkaline modification reduces the adhesion of the PVB to the glass. In contrast, the acidic improvement increases it, and provides higher adhesion stability in terms of the water content in the PVB film. Therefore, the adhesion depends on the amount of organic acid added and on the origin of the PVB and its plasticizers $[17,19]$.

\subsection{PVB Application}

Since the 1980s, greater experience with lamination and increases in the level of control of these technologies has led to the development of PVB films to encapsulate solar modules. 
Today, PVB is increasingly taking a leading role among the alternative encapsulating materials for solar cells, such as ethylene-vinyl acetate (EVA) and its copolymers $[15,16]$. For solar modules, reliable and long-term protection against external influences is required. Transparent plastic encapsulation materials contribute to the durability of photovoltaic modules, and thus contribute to the long-term production of electricity from solar radiation. The first world manufacturer to develop a special PVB film for use in solar modules was Kuraray Europe $\mathrm{GmbH}$, under the trademark Trosifol. Solar modules using PVB films have been successfully passing the outdoor weather test since the early 1980s [15,19]. To ensure module life and long-term energy production, cell encapsulation materials must exhibit certain important properties, such as mechanical cell protection, weather protection, electrical insulation, external shock resistance, oxygen and water vapor security, cell corrosion prevention, tailored adhesion to other components of the module (glass, cell, base film, contact), and of course high transparency and high protection against UV radiation (to prevent degradation of plastic) [19].

Many coatings, enamels, adhesives and inks are PVB-based due to their excellent hydroxyl-containing adhesive properties and the flexibility they can bring to thermoset materials. Hydroxyl groups allow the good wetting of most substrates, and provide reactive sites for chemical combination, self-crosslinking, or crosslinking with phenolics, epoxides, isocyanates, melamine or urea. They are used in both powder and liquid layers [15]. PVB resins can be used in furnaces or in enameled wires to cover magnetic wires, so that coils made of this wire can be easily bonded by heat (hot air bonding) at moderate temperatures $\left(110-110{ }^{\circ} \mathrm{C}\right)$, or by activating the solvent with ethanol or methanol. In metal-protective coatings, PVB is used as a primer to achieve effective corrosion inhibition due to its good adhesion to metal and it speed of drying. It improves the uniformity of the coating, minimizes the overlap of the individual layers, improves the adhesion, and increases the toughness and flexibility of the coating [14,15]. The combination of PVB, chromium pigment, phosphoric acid and the metal complex leads to the phosphatization of the metal surface. It acts as a corrosion-inhibiting pigment in the adhesive binder, which also supplies chromate ions to repair cracks in the phosphate film [15,16]. Adhesion is improved by firing at temperatures up to $140{ }^{\circ} \mathrm{C}$. Due to concerns about the toxicity of chromium compounds, systems using zinc borate, phosphate or sodium molybdate are increasingly used. Coating a metal foil (aluminum, brass, tin, lead, iron) with a PVB solution increases the resistance to moisture, as well as the absorbency [15].

Wooden bases are protected against discoloration by polyester and polyurethane coatings. Their combination with phenolic resins provides an excellent barrier against the leakage of terpenes from wood. In combination with nitrocellulose and emollient, skin dye is used. In general, though, it is also advisable to coat textiles to obtain water and stain resistance, without affecting the appearance [16]. In Europe, around 9 million vehicles will end their lives each year. One of the more important factors directly related to the use of newly recycled PVB is that laminated glass represents up to $3 \%$ of the total material in vehicles at the end of their service lives. This translates to about 480,000 tons per year, which comes from end-of-life vehicles. The use of an innovative recycling technology by companies that recycle automotive glass and laminated glass containing PVB film provides great economic benefits from the outset. The manufacturing costs for purified PVB will be ca. 4 to $5 \mathrm{EUR} / \mathrm{kg}$, while the current cost of pure PVB is between 9 and $13 \mathrm{EUR} / \mathrm{kg}$. An important aspect is that the customer obtains a recycled product with similar technical properties as the original material, which means that it can be applicable for primary use.

\section{Results}

\subsection{Composite Material from Recycled PVB-Fabrics from Waste Tyres}

When preparing the composite, we used constant mixing. Thermoplastics are almost exclusively prepared on twin-screw devices, which is a less demanding mixing process than single-screw devices with kneading and mixing elements included $[16,18]$. After purification of the fabric component of undesirable impurities, the fabrics were tested 
by thermal analysis, namely, differential scanning calorimetry, on the basis of which it is known that the material consists of two types of polyamides, PA 6 and PA 6.6, and minor amounts of PET and crystalline cellulose. Due to the fact that the aim of the work was to look for possible uses for this component, we used the separated fabric for the preparation of new composite materials reinforced with fabrics from waste tires [18]. The composite material was created by mixing two elements, and the matrix was a thermoplastic polyvinyl butyral, which is incorporated into car glass as a safety film. After its recycling a raw material with excellent properties is created $[12,14,18]$. Composite materials containing 10 to $80 \%$ fabrics were subjected to mechanical, thermomechanical and rheological testing for each composite material. The samples were also subjected to microscopic analyses by AFM-microscopy and FT-IR. At the same time, the composite materials with contents of 50 and $80 \%$ were tested in a climatic chamber, and the measurement was performed according to the relevant standard. The test was performed for 320 hours under the prescribed conditions $[13,18]$. From the tensile diagram, we can infer that the value of the tensile strength for the composite material with a 50\% fabric content is $7.223 \mathrm{MPa}$, and after $320 \mathrm{~h}$ it was $10.995 \mathrm{MPa}$. The value of relative elongation was $13.583 \%$, and after $320 \mathrm{~h}$ it was $8.426 \%$. For a composite material containing $80 \%$ fabrics, the value of the tensile strength was 5,086 MPa before testing in a climate chamber, and 7.026 MPa after $320 \mathrm{~h}$ [18]. The value of the relative elongation for a material with an $80 \%$ fabric content was $3.158 \%$, and after the climate chamber it was $3.907 \%$-the resulting composite material had a fabrics content of 10 to $80 \%$ by weight. Fabrics with each of these contents may have properties comparable to products with similar application levels as the newly created product [20].

Applicability of composite material [16,19]:

- Interior of buildings-base layer under wooden floating floors, protection against step noise, anti-vibration ability of floors, damping element for prefabricated stairs, the pad under a connecting material, application of the material in the construction industry;

- Exterior of buildings-driveways, sandpit cover;

- Garden construction-curbs, flower pots, weed protection, protection against unwanted root growth, protection of swimming pools against tearing of the base foil of swimming pools;

- Application of material in civil engineering-railway crossings, damping materials under rails, retarders, noise barriers on busy roads;

- Waste minimization - when recycling tires, the possibility of obtaining a fabric component that has been disposed of either by landfill or incineration, or used as an admixture in asphalt or concrete, in the cleaning of metal, as a filler in gymnastic equipment, etc.

\subsection{Composite Material from Recycled PVB-Fillers Are High-Strength Fibers}

Glass, carbon and aramid fibers were used in the research, as well as CordEnka, a synthetic fabric with excellent properties that is used in the tire industry [21]. Table 3 describes the mechanical properties of the tested materials.

Table 3. The measurement characteristics of geopolymer composite materials.

\begin{tabular}{ccccc}
\hline Filler & $\begin{array}{c}\text { E-Module } \\
\text { (MPa) }\end{array}$ & $\begin{array}{c}\text { Tensile Stress } \\
\text { (MPa) }\end{array}$ & $\begin{array}{c}\text { Elongation at Break } \\
\text { (\%) }\end{array}$ & $\begin{array}{c}\text { Humidity } \\
\text { (MPa) }\end{array}$ \\
\hline Glass Fiber (E-Glass) & 5000 & 1500 & 3.5 & 2.5 \\
Carbon Fiber & 150,000 & 2500 & 1.5 & 1.8 \\
Aramid Fiber & 100,000 & 2000 & 2.0 & 1.45 \\
CordEnka & 833,000 & 20,000 & 13.0 & 1.5 \\
\hline
\end{tabular}

Properties of PVB matrix thermoplastics $[18,20]$ :

- $\quad$ high relative elongation; 
- compared to thermosets, the thermoplastic has high temperature stability;

- generally, has very good life stability;

- possibility of recycling;

- higher viscosity than thermosets.

As part of the research, we focused on testing the pull-out effect [21], whereby the fibers were inserted only $3 \mathrm{~mm}$ and $5 \mathrm{~mm}$ into the PVB thermoplastic matrix. These experiments yielded the following results (Table 4).

Table 4. Strength characteristics of high-strength fibers in PVB matrix.

\begin{tabular}{|c|c|c|c|c|c|c|}
\hline \multirow[b]{2}{*}{ Filler } & \multicolumn{3}{|c|}{$3 \mathrm{~mm}$ vs. PVB (Pull Out) } & \multicolumn{3}{|c|}{5 mm vs. PVB (Pull Out) } \\
\hline & $\begin{array}{c}\text { Tensile Stress } \\
\text { (MPa) }\end{array}$ & $\begin{array}{c}\text { Elongation at Break } \\
(\%)\end{array}$ & $\begin{array}{l}\text { E-Module } \\
\text { (MPa) }\end{array}$ & $\begin{array}{l}\text { Tensile Stress } \\
\text { (MPa) }\end{array}$ & $\begin{array}{c}\text { Elongation at Break } \\
(\%)\end{array}$ & $\begin{array}{l}\text { E-Module } \\
\text { (MPa) }\end{array}$ \\
\hline $\begin{array}{l}\text { Glass Fiber } \\
\text { (E-Glass) }\end{array}$ & 128.70 & 2.45 & 4907.00 & 166.80 & 3.42 & 4430.00 \\
\hline Carbon Fiber & 95.40 & 1.35 & 5437.00 & 134.30 & 1.22 & 8452.00 \\
\hline Aramid Fiber & 228.70 & 1.39 & 7457.00 & 393.60 & 2.25 & $15,026.00$ \\
\hline CordEnka & 63.00 & 1.90 & 2936.00 & 124.00 & 6.30 & 2117.00 \\
\hline
\end{tabular}

As expected, the tensile strengths of these types of fibers in a thermoplastic PVB matrix are lower when the fiber is reinforced at a distance of $3 \mathrm{~mm}$ from the center of the matrix than when the fiber is inserted at a distance of $5 \mathrm{~mm}$ from the center of the matrix. The value of the tensile stress ranges from $63 \mathrm{MPa}$ to $228.7 \mathrm{MPa}$ for $3 \mathrm{~mm}$ insertion into the PVB matrix, while the values for the composite material with fiber inserted $5 \mathrm{~mm}$ from the middle of the PVB matrix are 124.0 MPa to 393.6 MPa. The elongation value for each thread ranges from 1.35 to $2.45 \%$ for the $3 \mathrm{~mm}$ fiber matrix. The results for a distance of $5 \mathrm{~mm}$ from the matrix are 1.22 to $6.30 \%$. The fibers and the matrix are elastically deformed. The stiffness of the fiber-matrix system depends on such parameters as the E-modulus of the fiber and the matrix, the volume ratio of the fibers to the matrix, the shear modulus of the matrix and the porous layer, and the loading conditions.

\subsection{Variability of Customized $P V B$}

Two or more polymers were prepared by mixing with non-polymeric additives (e.g., fillers, plasticizers, etc.). By adding polymers to the basic component of PVB, various variations in the final products were created (Figures 3 and 4) - substances that differ in their properties and use. To optimize the mixing of properties, we applied a feature model diagram (FMD) with a tree structure, the root (PVB) of which represents the concept, and the nodes describe the properties. The relationship between a parent property and a child property generally indicates that the child property requires the inclusion of a parent property. In general, we distinguish three basic types of properties [22]:

- Optional properties-Such properties that may or may not be included in the concept. These are properties that add value to the main features of the product. They are graphically represented by adding an empty circle to a given node;

- Mandatory properties-These are properties without a special notation that must be included in each instance of the concept. They represent the main features that identify the final product. They are graphically represented by adding a solid circle to a given node;

- Alternative properties-The concept may contain several sets of alternative properties, which may be optional or mandatory. They are graphically represented by an arc that connects two or more properties from a set of properties, with just one of them included in the concept instance. 


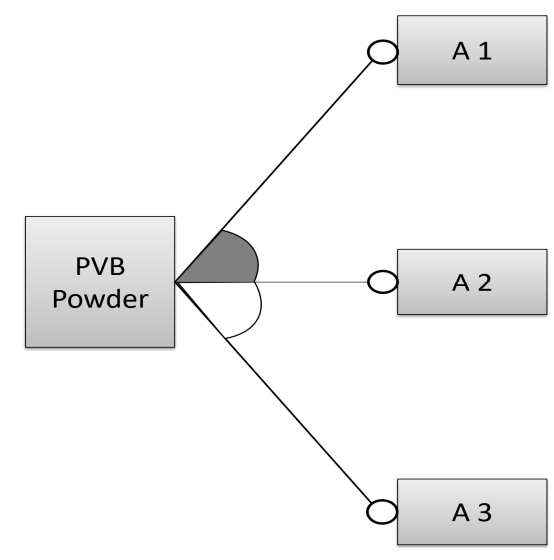

Figure 3. FMD PVB powder.

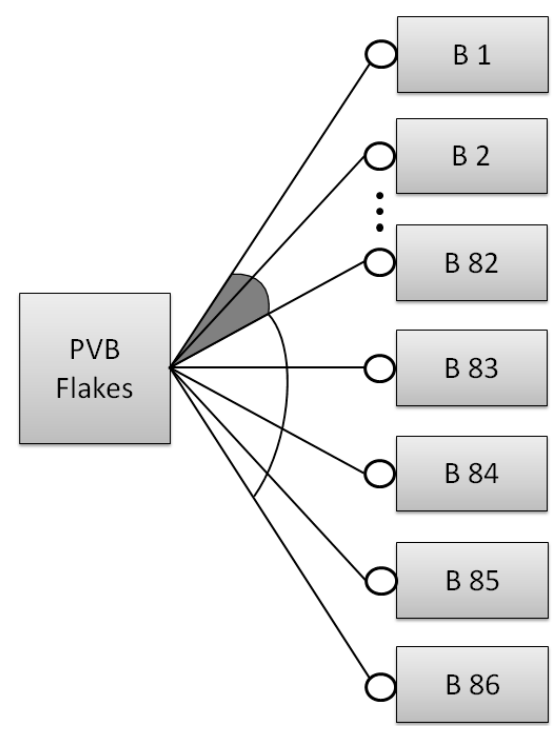

Figure 4. FMD PVB flakes.

The notation, according to Czarnecki and Eisenecker [23], represents the slightly modified and extended basic node of the property diagram, which is limited and supplemented by features. It is a set of properties, one of which includes one or more of the options. Graphically, this set is represented by a solid arc. However, in general, during the normalization of a property diagram, sets or properties containing one or more optional properties are replaced by other optional properties.

An important element of the property diagram is the variation point, which designates the node to which the optional, alternative, optionally alternative or or-properties, which are collectively referred to as variable properties, are attached. The point of variation in the property diagram represents the place where the variability in the properties of the concept is captured, and for this very reason, its explicit designation is important. For the purposes of applying mass customization to the production process, it is important to approach the "rules" of combinatorics and permutations, through which we can present the concepts of selecting possible elements from the set of all components. In general, if the order of chosen features is dependent, and combinations with the same content are not taken into account, we speak of varieties [24]. In cases wherein we select only a certain number of elements from the whole set of components, and each arrangement of elements is taken as 
a separate permutation, we no longer talk of factorials (since it is not calculated up to 1), and can generally refer to it as a ratio of factorials [24]:

$$
\frac{\mathrm{n} !}{(\mathrm{n}-\mathrm{k}) !}=\mathrm{n} \times(\mathrm{n}-1) \times(\mathrm{n}-2) \times \ldots \times(\mathrm{n}-\mathrm{k}+1)
$$

However, if we consider the case in which all ordered permutations of three elements are regarded as one combination, then the following holds [25]:

$$
\left(\begin{array}{l}
\mathrm{n} \\
\mathrm{k}
\end{array}\right)=\frac{\mathrm{n} !}{\mathrm{k} !(\mathrm{n}-\mathrm{k}) !}=\frac{\mathrm{n} \times(\mathrm{n}-1) \times(\mathrm{n}-2) \times \ldots \times(\mathrm{n}-\mathrm{k}+1)}{\mathrm{k} !}
$$

where $\mathrm{n}$ is the set of all elements and $\mathrm{k}$ is the selection of parts from the set $\mathrm{n}$. The calculation of the variability in the materials PVB dust and PVB flakes was realized on the basis of combinatorics and permutation, whereby we calculated the total number of variants of the materials that differ in compositional, chemical, physical and mechanical properties, which are subsequently related to their application and use in various industries.

\subsubsection{Customized PVB Powder}

Based on the analysis and the diagram of properties, we can state that in practice, PVB dust can be used in pure form (A1) or in combination with components $\mathrm{A} 2$ and $\mathrm{A} 3$, which, when added to the formula, becomes:

$$
\sum \text { PVB powder }=1+\left(\frac{n !}{\mathrm{k} 2 !(\mathrm{n}-\mathrm{k} 2) !}\right)+\left(\frac{\mathrm{n} !}{\mathrm{k} 3 !(\mathrm{n}-\mathrm{k} 3) !}\right)
$$

Specifically:

$$
\begin{gathered}
\sum \text { PVB powder }=1+\left(\frac{2 !}{1 !(2-1) !}\right)+\left(\frac{2 !}{2 !(2-2) !}\right)=1+\left(\frac{2 \times 1}{1}\right)+\left(\frac{2 \times 1}{2 \times 1 \times(0)}\right) \\
=1+2+1=4 \text { variants }
\end{gathered}
$$

\begin{tabular}{|c|c|c|c|c|}
\hline & Additive & Properties & Utilization & Application in Industry \\
\hline \multirow{7}{*}{$\begin{array}{c}\text { PVB powder } \\
\text { (industrial processing) }\end{array}$} & \multirow[t]{3}{*}{$\begin{array}{c}\text { A1 } \\
(\text { PVB powder } 100 \%)\end{array}$} & $\begin{array}{l}\text { Thermal stability up to } \\
\qquad 120^{\circ} \mathrm{C}\end{array}$ & $\begin{array}{l}\text { Binder for facade inks, } \\
\text { printing inks }\end{array}$ & $\begin{array}{l}\text { Building industry, } \\
\text { printing industry, } \\
\text { packaging industry } \\
\text { Electrical industry, }\end{array}$ \\
\hline & & Light stability & Covers & $\begin{array}{l}\text { automotive industry, } \\
\text { engineering industry }\end{array}$ \\
\hline & & Adhesion to surfaces & $\begin{array}{l}\text { Binder for adhesives, } \\
\text { emulsions, sprays for } \\
\text { structures }\end{array}$ & $\begin{array}{l}\text { Building industry, civil } \\
\text { engineering }\end{array}$ \\
\hline & \multirow[t]{2}{*}{$\begin{array}{c}\text { A2 } \\
\text { (Hexafluoro- isopropanol) } \\
\text { (HFIP) }\end{array}$} & Elasticity and rigidity & $\begin{array}{l}\text { Covers, surface layers, } \\
\text { protective tapes }\end{array}$ & $\begin{array}{l}\text { Electrical industry, } \\
\text { construction industry, } \\
\text { automotive industry, } \\
\text { engineering industry }\end{array}$ \\
\hline & & Thermal and light stability & $\begin{array}{l}\text { Insulation properties, heat } \\
\text { and light resistance }\end{array}$ & $\begin{array}{c}\text { Glass industry, energy } \\
\text { industry }\end{array}$ \\
\hline & \multirow{2}{*}{$\begin{array}{c}\text { A3 } \\
\text { (phenolic, epoxy, } \\
\text { melamine resins and } \\
\text { isocyanates) }\end{array}$} & Water resistance & Binder & $\begin{array}{l}\text { Automotive industry, } \\
\text { construction industry, } \\
\text { electrical industry }\end{array}$ \\
\hline & & $\begin{array}{c}\text { Increasing and decreasing } \\
\text { the viscosity of the } \\
\text { material }\end{array}$ & $\begin{array}{l}\text { Type of solvent used } \\
\text { (ethanol, toluene) }\end{array}$ & $\begin{array}{l}\text { Chemical industry, } \\
\text { printing industry }\end{array}$ \\
\hline
\end{tabular}

Customized PVB powder has four variants (A1, A2, A3, A2A3) of use, which, together with their specific properties, are discussed in Table 5.

Table 5. Properties and uses of customized PVB powder. 


\subsubsection{Customized PVB Flakes}

As with PVB powder, PVB flakes can be mixed with materials to increase their mechanical, chemical and physical properties. These, in turn, satisfy a wider array of consumers who, by customizing their desired material, can combine multiple input materials to create the desired final material that meets all of their specific material property requirements. For the calculation, we used the same relationship as for PVB dust, but her it was specifically:

$$
\begin{aligned}
\text { EPVB flakes }= & \left(\begin{array}{c}
\mathrm{n} 1 \\
\mathrm{k} 1
\end{array}\right)+\left(\frac{\mathrm{n} 2 !}{\mathrm{k} 2 !(\mathrm{n} 2-\mathrm{k} 2) !}\right)+\left(\frac{\mathrm{n} 2 !}{\mathrm{k} 3 !(\mathrm{n} 2-\mathrm{k} 3) !}\right)+\left(\frac{\mathrm{n} 2 !}{\mathrm{k} 4 !(\mathrm{n} 2-\mathrm{k} 4) !}\right) \\
& +\left(\frac{\mathrm{n} 2 !}{\mathrm{k} 5 !(\mathrm{n} 2-\mathrm{k} 5) !}\right) \\
\sum \text { PVB flakes }= & \left(\begin{array}{c}
82 \\
1
\end{array}\right)+\left(\frac{4 !}{1 !(4-1) !}\right)+\left(\frac{4 !}{2 !(4-2) !}\right)+\left(\frac{4 !}{3 !(4-3) !}\right)+\left(\frac{4 !}{4 !(4-4) !}\right) \\
= & \left(\frac{82 !}{1 !(82-1) !}\right)+\left(\frac{4 !}{1 !(3) !}\right)+\left(\frac{4 !}{2 !(2) !}\right)+\left(\frac{4 !}{3 !(1) !}\right)+\left(\frac{4 !}{4 !(0) !}\right) \\
= & \left(\frac{82 !}{1 !(82-1) !}\right)+\left(\frac{4 !}{1 !(3) !}\right)+\left(\frac{4 !}{2 !(2) !}\right)+\left(\frac{4 !}{3 !(1) !}\right)+\left(\frac{4 !}{4 !(0) !}\right) \\
= & \left(\frac{82 !}{1 !(82-1) !}\right)+\left(\frac{4 !}{1 !(3) !}\right)+\left(\frac{4 !}{2 !(2) !}\right)+\left(\frac{4 !}{3 !(1) !}\right)+\left(\frac{4 !}{4 !(0) !}\right) \\
= & \left(\frac{82 \times 81 \times 80 \times 79 \times 78 \times 77 \times 76 \times 75 \times 74 \times \ldots \times 1}{1 \times(81 \times 80 \times 79 \times 78 \times \ldots \times 1)}\right) \\
& +\left(\frac{4 \times 3 \times 2 \times 1}{1 \times(3 \times 2 \times 1)}\right)+\left(\frac{4 \times 3 \times 2 \times 1}{2 \times 1 \times(2 \times 1)}\right)+\left(\frac{4 \times 3 \times 2 \times 1}{3 \times 2 \times 1 \times(1)}\right) \\
& +\left(\frac{4 \times 3 \times 2 \times 1 \times}{4 \times 3 \times 2 \times 1 \times(0) !}\right)=82+4+6+4+1=97 \text { variants }
\end{aligned}
$$

\begin{tabular}{|c|c|c|c|c|}
\hline & Additive & Properties & Utilization & Application in Industry \\
\hline \multirow{10}{*}{$\begin{array}{l}\text { PVB flakes (basic form } \\
\text { after recycling) }\end{array}$} & PVB Flakes 100\% & Material flexibility & Insulation material & $\begin{array}{l}\text { Construction industry, } \\
\text { electrical industry }\end{array}$ \\
\hline & & Processing variability & $\begin{array}{l}\text { Easy material handling } \\
\text { during pressing, extrusion, } \\
\text { injection }\end{array}$ & $\begin{array}{l}\text { Construction industry, } \\
\text { electrical industry, }\end{array}$ \\
\hline & $\begin{array}{c}\text { PVB + waste tyres fabrics (wt. } \\
\% \text { from } 10 \text { to } 90 \% \text { ) }\end{array}$ & $\begin{array}{l}\text { Increasing the strength } \\
\text { characteristics (tensile stress, } \\
\text { E-modulus, shear strength) } \\
\text { depends on wt. \% proportion } \\
\text { of fabrics component. The } \\
\text { higher the proportion of } \\
\text { textile, the higher the strength } \\
\text { characteristics of the final } \\
\text { material. }\end{array}$ & $\begin{array}{l}\text { Facing material, floors, } \\
\text { partitions in production, } \\
\text { joining of portable fences, } \\
\text { benches, flower pots }\end{array}$ & $\begin{array}{l}\text { Building industry, } \\
\text { horticultural industry, } \\
\text { electrotechnical industry, } \\
\text { automobile industry }\end{array}$ \\
\hline & PVB + Aramid fiber (AF) & $\begin{array}{c}\text { Higher proportion of AF, } \\
\text { increases sensitivity to UV } \\
\text { radiation }\end{array}$ & Protective surfaces, tiles & $\begin{array}{l}\text { Construction industry, } \\
\text { electrical industry, }\end{array}$ \\
\hline & & $\begin{array}{l}\text { Resistance to abrasion, heat } \\
\text { and organic solvents } \\
\text { Non-conductive material }\end{array}$ & $\begin{array}{l}\text { Covers, protective covers, } \\
\text { protective surface treatments } \\
\text { Protective cover, covers }\end{array}$ & $\begin{array}{l}\text { automotive industry, } \\
\text { engineering industry }\end{array}$ \\
\hline & PVB + Carbon fabric (CF) & $\begin{array}{l}\text { Anticorrosion, } \\
\text { temperature resistance } \\
\text { Antistatic }\end{array}$ & $\begin{array}{l}\text { Cover, protective surfaces, } \\
\text { cover, packaging material } \\
\text { Washers }\end{array}$ & $\begin{array}{l}\text { Construction industry, } \\
\text { electrical industry, } \\
\text { Electrical industry, }\end{array}$ \\
\hline & PVB +Glass fabric (GF) & $\begin{array}{l}\text { Insulation properties, } \\
\text { material strength } \\
\text { Anticorrosion }\end{array}$ & $\begin{array}{l}\text { Insulation } \\
\text { tiling, stressed parts } \\
\text { covers }\end{array}$ & $\begin{array}{l}\text { Automotive industry, } \\
\text { engineering industry }\end{array}$ \\
\hline & \multirow{3}{*}{ PVB +CordEnka } & High strength & $\begin{array}{l}\text { Withstands high torque, } \\
\text { stressed components }\end{array}$ & \multirow{3}{*}{$\begin{array}{l}\text { Construction industry, } \\
\text { electrical industry, } \\
\text { automotive industry, } \\
\text { engineering industry }\end{array}$} \\
\hline & & Flexibility & $\begin{array}{l}\text { Reinforcement for } \\
\text { high-strength products }\end{array}$ & \\
\hline & & Fire resistance & Packaging material, covers & \\
\hline
\end{tabular}

Customized PVB flakes have 97 variants of material use, which, together with their specific properties, are discussed in Table 6.

Table 6. Properties and uses of customized PVB flakes. 


\subsection{Environmentally Suitable Material Recovery Options for Recycled PVB Products}

Under the Waste Act, No. 79/2015 is a method of waste recovery that prioritizes energy recovery. From the point of view of our evaluation, it includes:

- recycling;

- reusing the physico-chemical properties of the waste.

The most suitable solution is one that includes a model for the continuous use of waste raw material that adheres to its initial production intention, or involves the use of so-called waste-free technologies. The production process is practically a closed circle. It also includes the idea of reverse logistics, the primary goal of which is the direct reuse of the waste from a specific production. Within Slovakian and European legislation, the trend is to focus on reducing waste, especially via prevention. Prioritizing the recovery of waste over landfilling, which is only a temporary solution, plays an important role in determining the further technological processing of raw material waste. The main goal is to choose a method of recovery that does not endanger people and does not burden the environment (water, soil, air) [25,26].

\section{Discussion}

\section{Intelligent Design of Healthy Buildings through BIM and Knowledge Technologies}

As part of our and European legislation, the trend is focused on reducing the amount of waste, especially via prevention. The preferance for waste recovery over landfilling, which is only a temporary solution, plays an essential role in deciding on the further technological processing of raw material waste. The main goal is to choose a method of recovery that does not threaten people and does not burden the environment (water, soil, air). This solution cannot be random. Multiple studies and waste management approaches argue that there must be set processes and system solutions involved. This also reflects our understanding that a system or methodology must be designed to achieve healthy buildings, or that can addres how to proceed when in the project stage of designing buildings. Knowledge technologies can be an effective tool in the intelligent and systematic use of new, healthly building materials. Progress in information technology and systems can improve the processing and use of recycled materials to the greatest extent possible. Developing such materials (recycled polyvinyl butal) and the subsequent incoproation of findings into knowledge systems should be a priority. On this basis, we can make intelligent propositions pertaining to healthy buildings and material health (Figure 5).

The proposal in Figure 5 was created based on a survey carried out to monitor several projects of different natures. They were mainly residential buildings, and concerned sustainability, healthy environments, the quality of materials, price, and the method of material and parameter selection. Based on this, the resulting design also needs to be verified (i.e., the exact method of intelligent design, through a knowledge-based BIM database). The selection of reference construction projects on which this proposal is being verified is currently underway. In terms of the widespread use of intelligent modeling and simulation, it is interesting to verify this on several types of construction projects. Based on the comprehensive representation of construction projects, it will be possible to define more clearly for which types of construction, and which parameters related to the perception of quality and safety requirements, it will be most appropriate to apply the given model.

Intelligent design has several benefits, which are reflected in different types of construction projects. The material in question (PVB) can also be used in various types of construction. From this point of view, based on the experiences derived from research and practice, it can be stated that this method can be applied in almost all types of construction projects, and offers similar results, not only in terms of intelligent design but also in terms of the use of the material in question. Some limitations to specific requirements can also be encountered here. These mainly involve engineering projects and transport constructions, where the use of the mentioned material is not determined by its properties to the same extent as in residential constructions. However, suppose we address healthy buildings (often residential buildings and commercial, public buildings, office buildings, etc.). In 
that case, this method of intelligent design and the use of PVB will not give fundamentally different results, and they will be comparable. Of course, this is also subject to verification in specific construction projects, which will continue this study. However, from the data and information already obtained, the previous assertion is highly likely, and these results can be considered general.

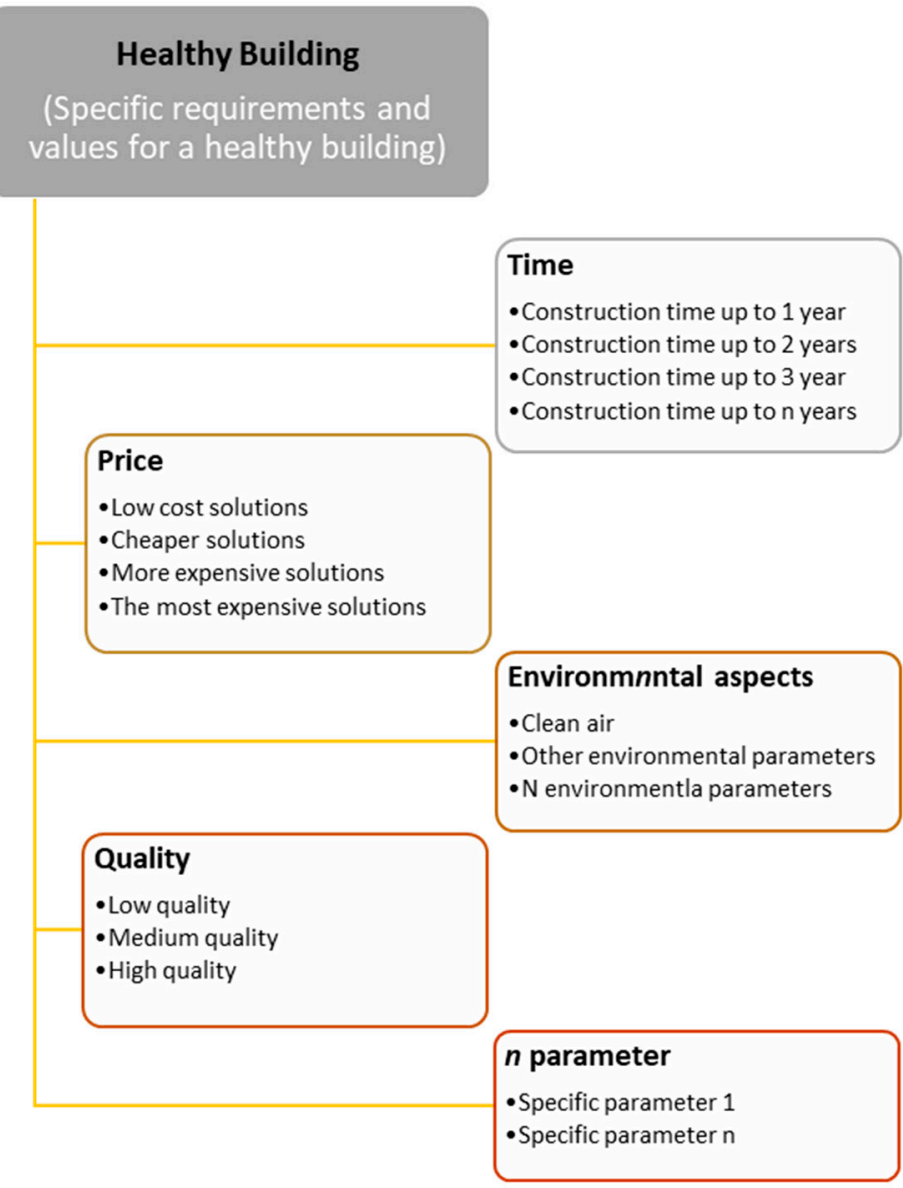

Figure 5. BIM-compatible knowledge database design.

BIM technology plays a significant role in intelligent design. BIMs are amongst the leading information technologies, and are an essential element of intelligent building modeling and design. BIM technologies using the information model of buildings work with the information that is the basis for finding the optimal model, and thus adhere to the research goals. The BIM application speeds up the building design process, contributes to digitization, and increases intelligent design.

The proposed knowledge database will contain multiple tracked and desired parameters. The basic concept is that each item (structural element or material) contains the information. Clearly, they must also be defined, and relationships between them must only pertain if the building and health benefits are intelligent. As part of this process, in the following, the selection of the structural material (also examined in the form of the recycled polyvinyl butyral) is described by the specified parameters and a knowledge system comprising this information and bonds (Figure 6). 


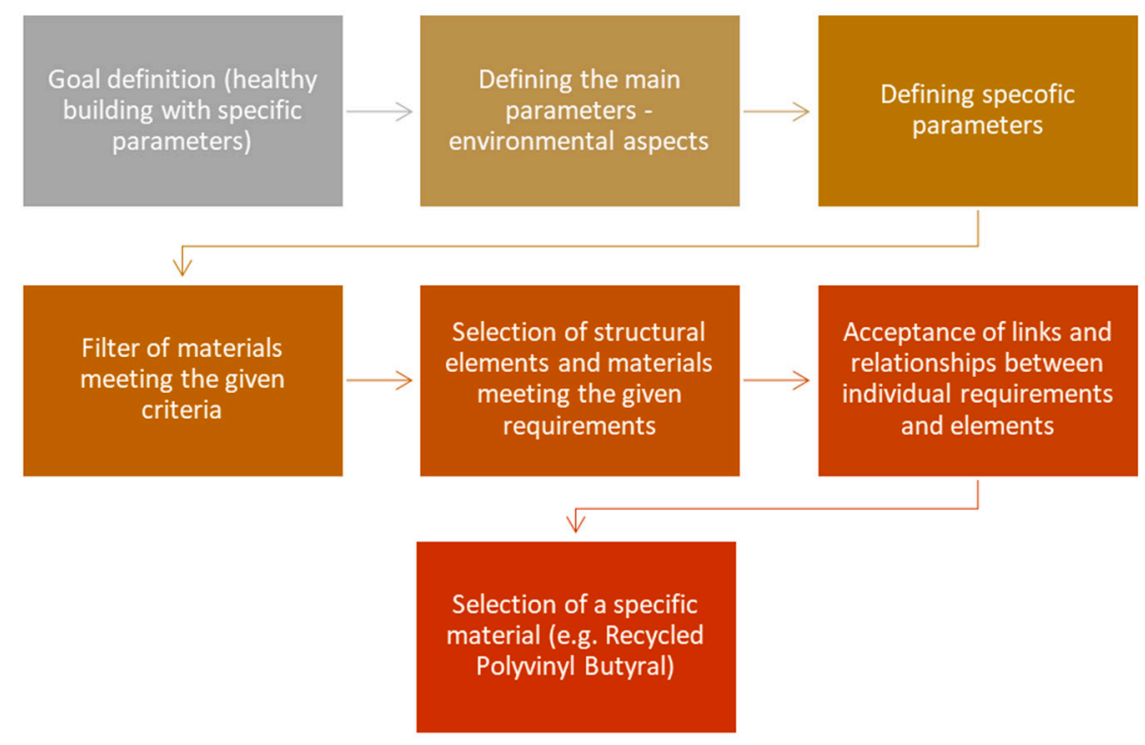

Figure 6. Specified parameters and a knowledge system comprising information and bonds.

These steps describe how the system can work methodically. The basis is a clear definition of the objective, including the specification of requirements. Creating a knowledge base for intelligent building design is a complex process defined by the relationships between the items. The acceptance of these defined links manifests the knowledge of the system. After the information is input, these processes acquire a knowledge character that filters and defines the monitored parameters. The knowledge system connected to the BIM environment can select the most suitable group of materials and structural elements that will lead to the design of a healthy building, using selected materials that meet the requirements for healthy living. Recycled polyvinyl butyral, which we have examined, may also be used as an item that meets these requirements as part of this selection.

The intelligent design of healthy buildings is based on advanced technologies that allow multiple processes to be performed automatically. Thanks to progress, knowledge databases and BIM technology are becoming an important tool that automates selected processes. The user (designer or even the investor) does not have to know all the materials, prices or quality properties. It is enough for them to clearly define the requirements of the output. In the case of the main goal, the design of a healthy building will have specific parameters in terms of the environment. Based on these requirements, according to the proposed method and the use of BIM technology and knowledge databases, the system will automatically design only combinations of materials (for example, in this research represented by recycled polyvinyl butyral) that meet health parameters. This level of intelligent building design will allow for automating many processes during the design phase, saving time, money, and even human capital. The main benefit is that this method of design will achieve the implementation of a healthy building, with all the attendant requirements.

\section{Conclusions}

Constructions concerned with the environment bring with them several challenges that project managers have to face. One of the challenges is to satisfy the specific requirements of the customer-to customize the final construction, wherein the customer has the choice of not only the appearance and dimensions of the building, but in this case the specific properties of the building as well, i.e., the material. The use of recycled PVB in the intelligent designing of healthy residential buildings will comprehensively reduce the use of fossil fuels for producing resin materials, and consequently reduce the $\mathrm{CO}_{2}$ emissions and energy consumption involved in the manufacturing of new materials. The research aimed to incorporate the results of the experiment into a knowledge system connected to 
the BIM environment, which can select the most suitable groups of materials and structural elements that will lead to the design of a healthy building, using selected materials (PVB) that meet the requirements of healthy living.

Author Contributions: Conceptualization, A.B. and L.K.; methodology, L.K. and M.B.; software, P.M.; validation, M.B., A.B. and T.M.; formal analysis, A.B. and L.K.; investigation, L.K., A.B. and T.M.; resources, M.B. and P.M.; data curation, L.K.; writing—original draft preparation, A.B., T.M. and L.K.; writing-review and editing, A.B.; visualization, A.B.; project administration, M.B. and P.M.; funding acquisition, P.M. and M.B. All authors have read and agreed to the published version of the manuscript.

Funding: This research was funded by the Slovak Research and Development Agency under the contract no. APVV-17-0549. Paper presents a partial research results of project VEGA 1/0828/17 "Research and application of knowledge-based systems for modelling cost and economic parameters in Building Information Modelling". The paper presents partial research results of project KEGA 059TUKE-4/2019 "M-learning tool for intelligent modeling of building site parameters in a mixed reality environment".

Institutional Review Board Statement: Not applicable.

Informed Consent Statement: Not applicable.

Data Availability Statement: Not applicable.

Conflicts of Interest: The authors declare no conflict of interest.

\section{References}

1. Vilčeková, S.; Harčárová, K.; Moňoková, A.; Krídlová Burdová, E. Life Cycle Assessment and Indoor Environmental Quality of Wooden Family Houses. Sustainability 2020, 12, 10557.

2. Krídlová Burdová, E.; Selecká, I.; Vilčeková, S.; Burák, D.; Sedláková, A. Evaluation of Family Houses in Slovakia Using a Building Environmental Assessment System. Sustainability 2020, 12, 6524. [CrossRef]

3. Vranay, F.; Piršel, L.; Kačík, R.; Vranayová, Z. Adaptation of HVAC Systems to Reduce the Spread of COVID-19 in Buildings. Sustainability 2020, 12, 9992. [CrossRef]

4. Al Ali, M.; Kmet', S.; Platko, P.; Bajzecerová, V.; Zeleňáková, M. The design and production of a suitable carrier for microwires used for non-contact detection of mechanical strains. Sustainability 2021, 13, 477.

5. Švajlenka, J.; Kozlovská, M.; Spišáková, M. Green and energy efficient solutions in the construction industry. In Proceedings of the GEOLINKS. Book 2: International Conference, Sofia, Bulgaria, 5-7 October 2020; pp. 245-251.

6. Sičáková, A.; Kováč, M. Relationships between Functional Properties of Pervious Concrete. Sustainability 2020, 12, 6318. [CrossRef]

7. Košičan, J.; Pardo Picazo, M.A.; Vilčeková, S.; Košičanová, D. Life cycle assessment and economic energy efficiency of a solar thermal installation in a family house. Sustainability 2021, 13, 2305. [CrossRef]

8. Kapalo, P.; Vilčeková, S.; Mečiarová, L'.; Dominita, F.; Adamski, M. Influence of Indoor Climate on Employees in Office Buildings-A Case Study. Sustainability 2020, 12, 5569. [CrossRef]

9. Gasparik, J.; Funtik, T.; Gasparik, M.; Alamro, B. Continuing increasing of quality management level in construction company using excellence model with software support. In Proceedings of the ISARC 2018-35th International Symposium on Automation and Robotics in Construction and International AEC/FM Hackathon: The Future of Building Things, Berlin, Germany, 20-25 July 2018; pp. 207-213.

10. Wen, Q.; Li, Z.; Peng, Y.; Guo, B. Assessing the Effectiveness of Building Information Modeling in Developing Green Buildings from a Lifecycle Perspective. Sustainability 2020, 12, 9988. [CrossRef]

11. Vasiliev, V.V.; Morozov, E.V. Mechanics and Analysis of Composite Materials; Elsevier Sciences: Amsterdam, The Netherlands, 2001.

12. Marini, I. Stoffliche Verwertung der Faserfraktion aus dem Altreifenrecycling, Technische Universität Wien, Projektbeschreibung. Available online: https:/ / docplayer.org/51729501-Stoffliche-verwertung-der-faserfraktion-aus-dem-altreifenrecycling.html (accessed on 15 May 2021).

13. Scrap Tire Recycling in Canada, CANMET Materials Technology Laboratory, 2005. Available online: https://www.researchgate. net/publication/273446776_Scrap_Tire_Recycling_in_Canada (accessed on 15 May 2021).

14. Sawyer, L.C.; Grubb, D.T.; Meyers, G.F. Polymer Microscopy, 3rd ed.; Springer: New York, NY, USA, 2008.

15. Barry, C.M.F.; Orroth, S.A. Processing of thermoplastics. In Modern Plastics Handbook; Harper, C.H.A., Ed.; McGraw-Hill: New York, NY, USA, 2000.

16. Dhaliwal, A.K.; Hay, J.N. The characterization of polyvinyl butyral by thermal analysis. Thermochim. Acta 2002, 391, 245-255. [CrossRef]

17. Kuraray.eu. Available online: www.Kuraray.eu (accessed on 20 May 2021). 
18. Knapcikova, L.; Radchenko, S.; Husar, J.; Radic, P.; Bernat, A. Experimental study of thermoplastics material reinforced by various types of high-strength fibers. MM Sci. J. 2016, 10, 1043-1046.

19. Sekisui chemical.com. Available online: https://www.sekisuichemical.com/products/search/1364225_38638.html (accessed on 20 May 2021).

20. Mortensen, A. Concise Encyclopedia of Composite Materials; Elsevier Sciences: Amsterdam, The Netherlands, 2007.

21. Mueller, M. Hybrid composite materials on basis of reactoplastic matrix reinforced with textile fibers from process of tyres recyclation. Agron. Res. 2015, 13, 700-708.

22. Czarnecki, K.; Helsen, S.; Eisenecker, U.W. Staged Configuration Using Feature Models. In International Conference on Software Product Lines; Springer: Berlin, Germany, 2004. [CrossRef]

23. Czarnecki, K.; Eisenecker, U.W. Generative Programming: Methods, Tools, and Applications; Addison-Wesley Professional: Reading, MA, USA, 2000; p. 864.

24. Modrak, V. Mass Customized Manufacturing; CRC Press: Boca Raton, FL, USA, 2016; p. 332.

25. Straka, M.; Taušová, M.; Rosová, A.; Cehlár, M.; Kačmáry, P.; Sisol, M.; Ignácz, P.; Farkas, C. Big data analytics of a waste recycling simulation logistics system. Pol. J. Environ. Stud. 2020, 29, 2355-2364. [CrossRef]

26. Culkova, K. Development of chosen social and economic indicators of using raw materials in the context of sustainability in Slovakia. In 4th EAI International Conference on Management of Manufacturing Systems: MMS 2019; Springer Nature: Basingstoke, UK, 2020; pp. 285-297. [CrossRef] 